\title{
Diversity and distribution of coral-associated bacteria
}

\author{
Forest Rohwer ${ }^{1, *}$, Victor Seguritan ${ }^{2}$, Farooq Azam $^{3}$, Nancy Knowlton ${ }^{3,4}$ \\ ${ }^{1}$ Department of Biology, LS317, and ${ }^{2}$ Department of Computational Sciences, San Diego State University, \\ San Diego, California 92182-4614, USA \\ ${ }^{3}$ Marine Biology Research Division, University of California, San Diego, Scripps Institution of Oceanography, \\ La Jolla, California 92093-0202, USA \\ ${ }^{4}$ Smithsonian Tropical Research Institute, Apartado 2072, Balboa, Republic of Panama
}

\begin{abstract}
Coral reefs are the most biodiverse of all marine ecosystems; however, very little is known about prokaryotic diversity in these systems. To address this issue, we sequenced over 1000 bacterial 16S rDNAs from 3 massive coral species (Montastraea franksi, Diploria strigosa, and Porites astreoides) in Panama and Bermuda. Analysis of only 14 coral samples yielded 430 distinct bacterial ribotypes. Statistical analyses suggest that additional sequencing would have resulted in a total of 6000 bacterial ribotypes. Half of the sequences shared $<93 \%$ identity to previously published $16 \mathrm{~S}$ sequences, and therefore probably represent novel bacterial genera and species; this degree of novelty was substantially higher than that observed for other marine samples. Samples from the Panama corals were more diverse than those from Bermuda, paralleling diversity gradients seen in metazoans. The coral-bacteria associations were non-random. Different coral species had distinct bacterial communities, even when physically adjacent, while bacterial communities from the same coral species separated by time $(\sim 1 \mathrm{yr})$ or space $(3000 \mathrm{~km})$ were similar. Analysis of the branching coral Porites furcata showed that bacterial ribotypes can also be structured spatially within colonies. Therefore, corals and reefs represent landscapes of diverse, ecologically structured prokaryotic communities.
\end{abstract}

KEY WORDS: Coral $\cdot$ Bacteria $\cdot 16 \mathrm{~S}$ rDNA $\cdot$ Biodiversity

\section{INTRODUCTION}

Coral reefs are the most diverse of all marine ecosystems, although most of this diversity remains uncharacterized. Estimates of eukaryotic species richness range from 650000 to over 9 million; however, these crude estimates are based upon extrapolation from insects in tropical rainforests (Reaka-Kudla 1997) and a partial count of organisms in a coral reef aquarium in Baltimore (Small et al. 1998). Similarly, 2 recent analyses of biodiversity patterns were based primarily or exclusively on the numbers of corals and fishes (Bellwood \& Hughes 2001, Roberts et al. 2002), organisms

*Email: forest@sunstroke.sdsu.edu that represent only a small fraction of the total diversity on reefs.

Prokaryotes represent most of the diversity on the planet and are almost certainly the most diverse component of coral reef communities. However, prokaryotic members of coral reefs have largely been ignored in biodiversity analyses. Moreover, the cultureindependent techniques that have revolutionized our knowledge of planktonic marine bacteria (reviewed in Giovannoni \& Rappe 2000) have not been employed systematically to study the bacteria living on coral reefs until recently (Rohwer et al. 2001, Frias-Lopez et al. 2002, Durkin et al. unpubl.).

Corals harbor diverse and abundant prokaryotic communities (DiSalvo \& Gundersen 1971, Sorokin 
1973, Mitchell \& Chet 1975, Ducklow \& Mitchell 1979, Pascal \& Vacelet 1981, Segel \& Ducklow 1982, Herndl \& Velimirov 1986, Paul et al. 1986, Williams et al. 1987, Shashar et al. 1994, Ritchie \& Smith 1995, 1997, Santavy 1995, Santavy et al. 1995, Kushmaro et al. 1996, Santavy \& Peters 1997, Rohwer et al. 2001, Frias-Lopez et al. 2002, Durkin et al. unpubl.). Whether these communities are just passive associations with water column bacteria or if they are specific associations with ecological importance is in dispute. Ritchie \& Smith (1997) used carbon source utilization patterns of bacteria cultured from the mucus layer (aka: mucopolysaccharide layer, MPSL; coral surface microlayer, CMS) to demonstrate that Caribbean coral species had unique, species-specific mucus-associated microbial communities. Rohwer et al. (2001) built upon this work and used a 16S rDNA culture-independent method (PCR and denaturing gradient gel electrophoresis, DGGE) to demonstrate that Montastraea franksi had a diverse bacterial community that was similar in 25 samples from 5 reefs, up to $10 \mathrm{~km}$ apart. Comparison of coralassociated and overlaying water column bacterial communities in this study showed that there is almost no overlap (Rohwer et al. 2001). Similarly, Frias-Lopez et al. (2002) and Durkin et al. (unpubl.) found the bacteria in overlaying water were not the same as those associated with corals. Santavy (1995) observed that Porites astreoides harbors a bacterial species, possibly Moraxella sp., that forms ovoids within P. astreoides and seems to participate in the normal life cycle of healthy corals. Other studies have shown that certain species of nitrogen-fixing bacteria are associated with corals and/or their skeletons (Williams et al. 1987, Shashar et al. 1994). Although these data support the hypothesis that corals harbor unique microbiota, inconsistencies across studies (Frias-Lopez et al. 2002 vs Rohwer et al. 2001) and across time (Durkin et al. unpubl.) raise many questions about the specificity and dynamics of associations between corals and bacteria.

Here, we analyzed the uncultured prokaryotic diversity of 3 coral species (Montastraea franksi, Diploria strigosa, and Porites astreoides) from 2 widely separated western Atlantic locations (Panama and Bermuda). Our results show that microbial diversity on corals is very high and some bacteria form speciesspecific associations with corals.

\section{MATERIALS AND METHODS}

Sampling. The sites sampled in this study were Whale Bone Bay, Bermuda (BER1), Hog Breaker Reef, Bermuda (BER2) and Bocas del Toro, Panama (Rohwer et al. 2001, PAN2, PAN4, and PAN5; Table 1). A punch and hammer were used to remove $1.3 \mathrm{~cm}$ diameter cores from the upper surfaces of 5 Montastraea franksi, 4 Diploria strigosa and 5 Porites astreoides colonies between 3 and $10 \mathrm{~m}$ in depth. The sampled corals were separated by distances of at least $10 \mathrm{~m}$. However, 1 cluster of all 3 species (colonies separated by $<25 \mathrm{~cm}$ ) was sampled in both Bermuda (BER1) and Panama (PAN5-00) in order to determine if proximity influenced the extent to which communities were similar. For $P$. furcata, large patches were selected haphazardly from PAN1 to PAN4 at depths of $\sim 3 \mathrm{~m}$. In each patch, 1 central (In) and 1 peripheral (Out) branch was harvested. From each complete branch a $\sim 1 \mathrm{~cm}$ 'Tip' (T) and 'Middle' (M) section was removed. All of the corals appeared disease-free at the time of sampling.

The samples were immediately placed in a plastic bag underwater. At the surface, each sample was washed twice with $0.2 \mu \mathrm{m}$ filtered and autoclaved seawater to remove any loosely associated microbes and

Table 1. Percentages of bacterial ribotypes and groups associated with samples from Porites astreoides, Diploria strigosa and Montastraea franksi, based on sequencing of 16S rDNA libraries ( $\mathrm{n}=$ number of clones sequenced). The distribution of bacterial groups across coral species deviates significantly from random expectation based on the number of clones sequenced per species $\left(\chi^{2}>800, p<0.001,12 \mathrm{df}_{;} 3\right.$ coral species, 7 microbial groups); the largest excesses over random expectation are in bold. One sample of each coral species was collected from colonies separated by only 20 to $50 \mathrm{~cm}$ in both Bermuda (BER1) and Panama

(PAN5-00). PA1 is a $\gamma$-proteobacterium ribotype exclusively associated with $P$. astreoides

\begin{tabular}{|c|c|c|c|c|c|c|c|c|c|c|c|c|c|c|c|}
\hline & \multicolumn{5}{|c|}{ Porites astreoides } & \multicolumn{4}{|c|}{ Diploria strigosa } & \multicolumn{5}{|c|}{ Montastraea franksi } & \multirow[t]{2}{*}{ Av. } \\
\hline & BER1 & BER2 & PAN4 & PAN5-99 & PAN5-00 & BER1 & BER2 & PAN4 & PAN5-00 & BER1 & BER2 & BER2 & PAN2 & PAN5-00 & \\
\hline$\gamma-$ PA1 & 40 & 92 & 72 & 77 & 27 & 0 & 0 & 0 & 0 & 0 & 0 & 0 & 0 & 0 & 22 \\
\hline$\gamma$ - Other & 13 & 5 & 2 & 14 & 22 & 13 & 15 & 26 & 18 & 20 & 12 & 35 & 15 & 20 & 16 \\
\hline$\alpha$ & 9 & 1 & 9 & 0 & 10 & 7 & 11 & 21 & 26 & 25 & 34 & 15 & 19 & 47 & 17 \\
\hline CFB & 13 & 0 & 0 & 0 & 7 & 43 & 28 & 17 & 26 & 8 & 3 & 6 & 19 & 9 & 13 \\
\hline $\mathrm{BC}$ & 0 & 0 & 0 & 7 & 15 & 32 & 24 & 35 & 26 & 12 & 4 & 11 & 4 & 11 & 13 \\
\hline Cyano & 6 & 0 & 17 & 2 & 8 & 0 & 12 & 0 & 0 & 10 & 4 & 2 & 7 & 10 & 6 \\
\hline Other & 18 & 2 & 1 & 0 & 11 & 5 & 10 & 3 & 3 & 25 & 42 & 31 & 37 & 2 & 14 \\
\hline $\mathrm{n}$ & 61 & 143 & 88 & 54 & 73 & 75 & 126 & 81 & 81 & 87 & 82 & 70 & 62 & 95 & \\
\hline
\end{tabular}


then placed on ice. The samples were transported back to the field station $(<2 \mathrm{~h})$ and each core was airbrushed (80 psi) with 10X TE (100 mM Tris[hydroxymethyl]aminomethane hydrochloride $\mathrm{pH}$ 8.0/10 mM EDTA) to remove the tissue and associated microbes. The slurry was aliquoted into cryovials and frozen.

Amplification and sequencing. As described before (Rohwer et al. 2001), total DNA was prepared from the coral samples using the UltraClean Soil DNA Kit (Mo Bio) and subjected to PCR using primers specific to bacterial 16S rDNA (i.e. 27F and 1492R; Amann et al. 1995). The resulting PCR products were cloned and inserts from the library were sequenced with the $27 \mathrm{~F}$ primer. A total of 1178 sequences were obtained.

Sequence analysis. A Java program, called FastGroup (Seguritan \& Rohwer 2001), was written that (1) trims ambiguous bases (i.e. ' $N$ ') from the 5' end; and (2) trims all sequence extending 3 ' of the conserved position at 534. Using this trimming protocol, sequences of $\sim 500 \mathrm{bp}$ were obtained that contained the third hypervariable region (V3) of the bacterial 16S rDNA. After trimming, FastGroup compares each sequence to every other in the library and groups them according to user-defined parameters. For this manuscript, any two $16 \mathrm{~S}$ rDNAs that were $\geq 97 \%$ identical with no gaps $>2$ bp were considered the same ribotype. Previously we have shown that this method of library construction and analysis yields results essentially the same as global alignments (Fig. 3 in Seguritan \& Rohwer 2001). Our $97 \%$ criterion follows the recommendations of numerous authors (Wayne et al. 1987, Stackebrandt \& Goebel 1994, Hagström et al. 2000). Although defining bacterial species based on rDNA similarity/identity remains controversial (Ward 1998), it is the best available method for studies of microbial diversity based on sequence data. Our choice of a $97 \%$ criterion was conservative, because bacteria with essentially identical (i.e. $>99 \%$ ) $16 \mathrm{~S}$ rDNAs can be quite different in their genomes (Perna et al. 2001) and ecological niches (Moore et al. 1998). Using a $99 \%$ criterion would increase the number of observed ribotypes by about $20 \%$. Therefore, all estimates of diversity presented here are minimums.

To determine how many errors were introduced during cloning and sequencing, we produced a 16S rDNA library with $E$. coli genomic DNA and analyzed it using the same protocols. Thirty sequences from this library were globally aligned using ClustalX, and the number of gaps and miscalled bases was counted. A total 15210 positions were investigated and 37 miscalled bases/gaps were observed, making the average PCR and sequencing error $0.243 \%$. Since this error rate is much lower than the $3 \%$ we are allowing by describing a ribotype as $97 \%$ identical, the influence of PCR and sequencing errors on our results should be nil.
Richness estimation. The true number of ribotypes represented by the libraries was estimated based on the occurrence of singlets and doublets using the Chao 2 estimator $\left(\mathrm{S}^{*}{ }_{2}\right.$; Chao 1984, Colwell \& Coddington 1994). Chao 2 calculations only require data on the presence or absence of a particular ribotype in 2 samples. This makes Chao 2 more appropriate for this data set than other estimators that depend on the relative numbers of particular ribotypes (e.g. Chao 1), and thus would be affected by PCR biases and 16S rDNA copy number per cell.

Bacterial group assignment. To assign groups, the trimmed and dereplicated sequences were aligned using ClustalX (Thompson et al. 1994, 1997), and a Neighbor-Joining tree was constructed. The divisions were identified by including multiple representatives from all of the major microbial groups in the ClustalX alignment. These classifications were confirmed by BLASTN analyses (Altschul et al. 1990, 1997, Benson et al. 2000) to identify the closest hit in GenBank. In most cases, the BLASTN and ClustalX/Tree assignments agreed; when there was a conflict, the assignment made from the Neighbor-Joining tree was used. The 16S rDNA sequence from the chloroplast of the dinoflagellate Heterocapsa triquetra was also included in the alignment to show that the primers did not amplify plastid sequences from zooxanthellae. The 'other' category thus includes plastids from other organisms (perhaps cyanobacteria) and sequences whose placement was ambiguous (i.e. a conflict between BLAST results and Neighbor-Joining tree, and weakly supported position within the tree). The percentages in Table 1 represent the number of times that a particular $16 \mathrm{~S}$ rDNA group appeared in the 16S rDNA library. Due to PCR bias and the various numbers of 16S rDNA copies per cell, the absolute abundance of any particular bacterial group must be interpreted with caution. We did, however, take 2 steps to reduce PCR bias. First, for each sample, 3 different concentrations of input DNA were used in the PCR and the lowest concentration that gave a signal was cloned and sequenced. Second, for each sample, 2 separate PCR libraries were made on different days; about $1 / 2$ the clones actually sequenced came from each of the separate libraries.

T-RFLP analysis. Bacterial communities of Porites furcata were analyzed by T-RFLP of the 16S rDNA (Liu et al. 1997, Moesender et al. 1999). DNA prepared from the samples was subjected to PCR as described above. The 27F primer used in this PCR was labeled with ${ }^{32} \mathrm{P}$ rATP using polynucleotide kinase. Primers and salts were removed from the PCR products using a Qiagen PCR clean-up kit. Five $\mu l$ of the products were then cut with HaeIII and analyzed using denaturing 5\% PAGE. The resulting gel was dried and exposed to film. 


\section{RESULTS}

The 14 coral samples contained a total of 430 bacterial ribotypes (AF365440 to AF365869). The most abundant single ribotype was observed in 205 clones, but most sequences were observed in 10 clones or less (Fig. 1). Although the absence of an asymptote in the species accumulation curve makes it difficult to accurately estimate the true number of bacterial ribotypes in these samples (Hughes et al. 2001), statistical analysis using the Chao 2 estimator (Chao 1984, Colwell \& Coddington 1994) suggests that the combined libraries may have contained as many as 6000 distinct bacterial ribotypes in total. Panama had a significantly larger number of bacterial ribotypes relative to the number of clones sequenced than did Bermuda (Table 1; 265 ribotypes in 534 clones vs 187 ribotypes in 644 clones, respectively; $\chi^{2}>32,1 \mathrm{df}, \mathrm{p}<0.001$ ). This suggests that global patterns of relative diversity found in coral reef metazoans (Roberts et al. 2002) may be paralleled by coral-associated prokaryotes.

Over $80 \%$ of the sequences exhibited $<97 \%$ identity to the nearest GenBank entry. To compare this level of novelty with other bacterial communities, we assembled 16S rDNA libraries from previously published data for coral-associated bacteria (Frias-Lopez et al. 2002), marine snow (Rath et al. 1998), coral reef waters and a random subset of marine GenBank sequences (Fig. 2). Half of the coral-associated bacterial sequences in our library and $41 \%$ of the sequence in the Frias-Lopez library were $<93 \%$ identical to previously characterized 16S rDNAs. In contrast, the majority of sequences in the other libraries were $>93 \%$ identical to previously described $16 \mathrm{~S}$ rDNAs. For the random marine and reef water libraries, the majority ( 74 and $84 \%$, respectively) of the sequences were $\geq 97 \%$ identical to other 16S rDNAs in the database. Because the Reef Water library consisted of sequences from tropical areas, it does not appear that our finding of high nov-

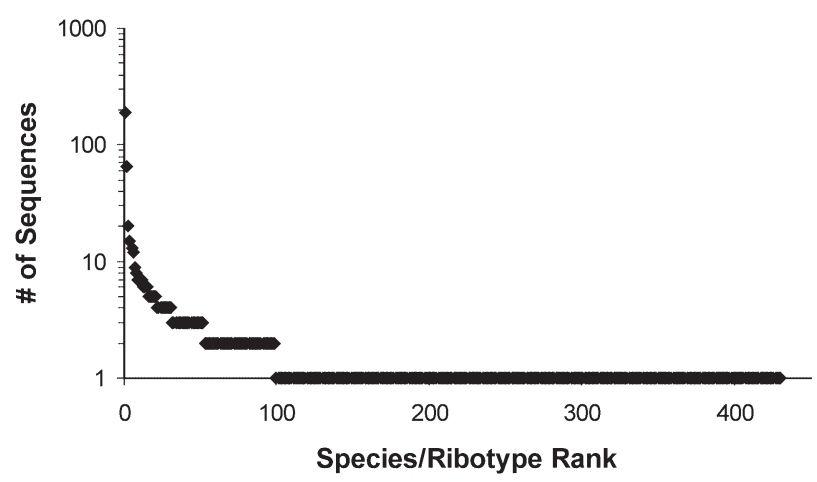

Fig. 1. Frequency distribution for the 430 distinct bacterial ribotypes detected among 1178 clones from 14 coral samples

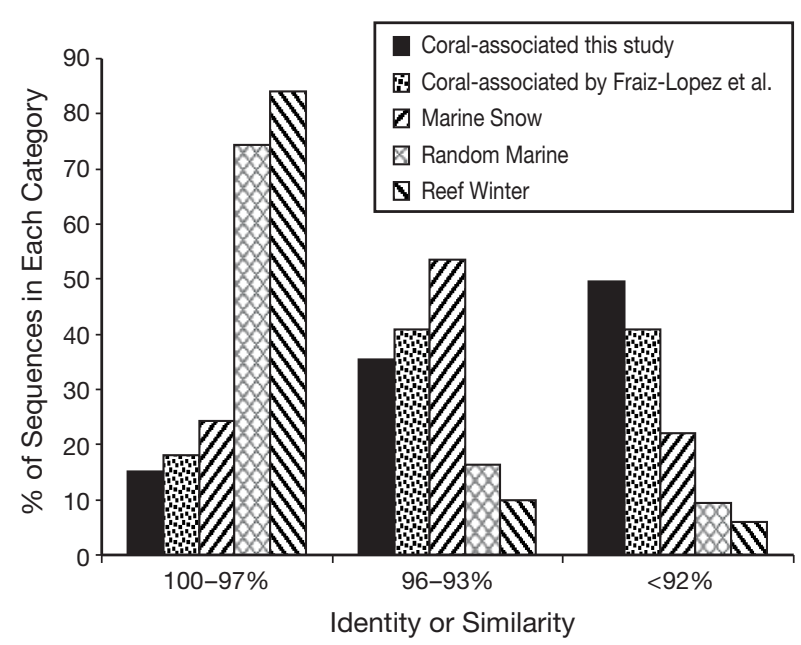

Fig. 2. Percent identity for four marine bacterial 16S rDNA libraries analyzed by BLASTN against GenBank: (1) coralassociated, this study (430 sequences from this study); (2) coral-associated (Tables 1, 2 \& 3 in Frias-Lopez et al. 2002; similarities reported for 81 sequences on healthy corals); (3) marine snow library (39 sequences from marine snowassociated bacteria; Rath et al. 1998); (4) random marine library (constructed by picking 100 16S marine bacterial rDNA sequences at random from GenBank); and (5) Reef Water library (107 sequences obtained using a 'bacteria coral' keyword search of GenBank, consisting primarily of cloned planktonic marine prokaryotes from surface waters over Pacific coral reefs)

elty in the coral-associated bacterial community is due to warm water per se. None of the coral-associated bacterial 16S rDNAs belonged to the ubiquitous marine groups SAR11 and SAR116 (Giovannoni \& Rappe 2000).

On average, the most common identifiable groups found in these libraries (Table 1) were $\gamma$-proteobacteria (38\%), followed by $\alpha$-proteobacteria $(17 \%)$, Bacillus/ Clostridium (BC; $13 \%)$, Cytophaga-Flavobacter/Flexibacter-Bacterioides $\left(\mathrm{CFB}_{;} 13 \%\right)$ and cyanobacteria $(6 \%)$; unidentifiable or other bacterial groups and plastids (not from zooxanthellae) accounted for the remaining $14 \%$ of the $16 \mathrm{~S}$ rDNAs.

The abundance of different bacterial groups varied substantially across samples, and some of these bacterial groups were significantly more common in particular coral species (Table 1). For example, the BC and CFB groups made up $\geq 50 \%$ of the bacterial $16 \mathrm{~S}$ rDNA sequences in all 4 Diploria strigosa samples, but they never accounted for more than $25 \%$ of $16 \mathrm{~S}$ rDNA sequences in the Porites astreoides and Montastraea franksi libraries. At a finer taxonomic level, the $5 \mathrm{M}$. franksi samples all contained large percentages of closely related $\alpha$-proteobacteria. This finding confirms our earlier report of a specific $\alpha$-proteobacterium ribotype on $25 M$. franksi samples from Panama, which 
was identified using DGGE (Rohwer et al. 2001). Similarly, the microbial community associated with P. astreoides always contained a specific $\gamma$-proteobacterium ribotype (AF365457, PA1 in Table 1). We also observed a ribotype that was always associated with Porites furcata (PF1), much in the same way the PA1 was always associated with $P$. astreoides. Subsequent sequencing of this PF1 band showed that it is a $\gamma$-proteobacterium closely related to PA1 (data not shown). The specificity of associated prokaryotes was maintained even when corals of different species were located immediately adjacent to each other. Of the 94 bacterial ribotypes observed in the 3 adjacent Bermuda samples, only 1 was present on 2 of the 3 corals and none were present on all 3. Similarly, in the Panama samples, only 1 out of the 101 observed bacterial ribotypes was shared between samples from 2 adjacent colonies of different species.

Because most bacterial ribotypes were observed only once, we separately examined the distribution patterns of the 34 bacterial ribotypes that occurred in more than 1 coral sample. Twenty-nine of these occurred only on the same coral species, a proportion that is highly significantly different $\left(\chi^{2}>35,1 \mathrm{df}, \mathrm{p}<0.001\right)$ from what would be expected. This fact, combined with previous analyses of water samples above corals (Ritchie \& Smith 1995, Rohwer et al. 2001, Frias-Lopez et al. 2002, Durkin unpubl.), strongly suggested that the observed patterns were not due to contamination by water column bacteria.

Bacterial ribotypes were also structured within some corals. The tips of Porites furcata harbored a specific ribotype (upper arrow, Fig. 3A) that was absent from the mid-sections of the same branches.

\section{DISCUSSION}

\section{Diversity of coral-associated bacteria}

Metazoan biodiversity on coral reefs is higher than in any other marine environment. Our results indicate that bacterial richness associated with corals is also very high, with an estimated 6000 ribotypes in the 14 libraries. By comparison, using the same $97 \%$ criteria for grouping $16 \mathrm{~S}$ rDNA sequences, there were only 1117 unique pelagic marine ribotypes in GenBank as of August 2001 (Hagström et al. 2002).

Our results also suggest that most of the coral-associated bacteria are novel at the genus and species level. Half of the sequences shared $<93 \%$ identity to previously published $16 \mathrm{~S}$ sequences (a commonly used criterion for proposing novel genera) and $35 \%$ of the sequences were $<97 \%$ identical (a commonly used criterion for proposing novel species). This degree of nov-

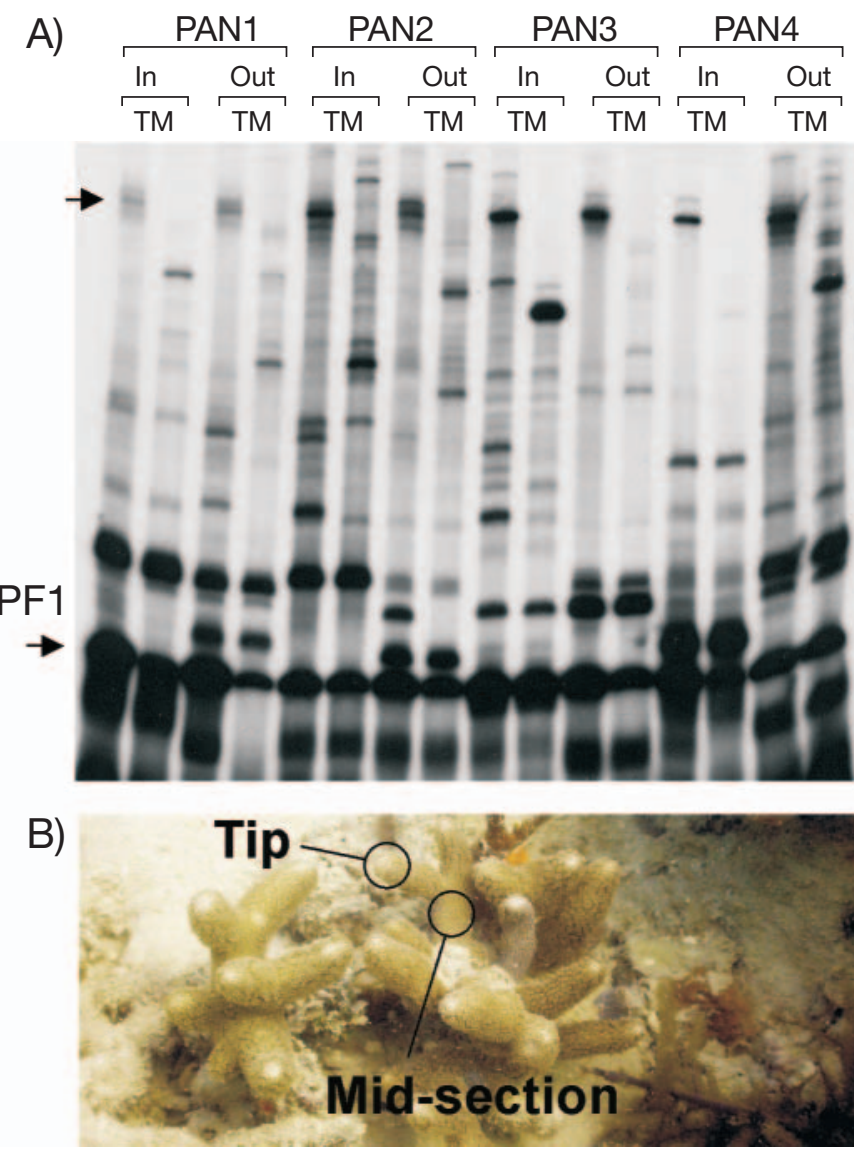

Fig. 3. Small-scale patchiness of bacteria associated with Porites furcata from Panama. (A) At each of 4 sites, 1 branch was collected from the approximate center of $P$. furcata patch (In) and 1 branch from the edge (Out). A $1 \mathrm{~cm}$ section of the tip (T) and mid-section $(\mathrm{M})$ were then harvested from each branch and analyzed using T-RFLP. The top arrow indicates a 16S rDNA fragment only present in the tip samples. The bottom arrow indicates a bacterial ribotype, PF1, always associated with $P$. furcata that is closely related to PA1 found on Porites astreoides.

(B) Example of the bleached tips and mid-section of $P$. furcata

elty was substantially higher than that observed for other marine samples and is consistent with the level of novelty found by Frias-Lopez et al. (2002). This level of novelty will undoubtedly decline as more studies of coral-associated bacteria are carried out. It is striking, however, that there is essentially no overlap between the 16S rDNAs found in this study and those that have been reported previously (Rohwer et al. 2001, FriasLopez et al. 2002).

One of our more intriguing findings was that the diversity of coral-associated bacteria appears to be higher in Panama than Bermuda, paralleling diversity gradients seen in metazoans. Although this difference was statistically significant, additional studies are required to confirm the generality of this trend. 


\section{Do corals harbor specific microbiotas?}

If bacteria routinely form species-specific associations with corals, it would be expected that such associations would be maintained over space and time. As shown in Table 1 , there is statistical evidence that coral-bacterial associations are so maintained. Most striking is the association of the $\gamma$-proteobacteria PA1 with Porites astreoides. We have now confirmed this finding in over 50 P. asteroides samples using specific PCR (data not shown). It remains to be determined if this ribotype comprised the bacteria in ovoids reported by Santavy (1995). The finding that $P$. furcata also harbors a specific $\gamma$-proteobacteria (lower band, Fig. 3A) that is closely related to PA1 suggests that this bacterial group may associated with Porites spp. generally.

Our data also indicate that there may be other groups of related bacteria that preferentially associate with other corals (Table 1). We observed that a group of closely related $\alpha$-proteobacteria (Silicibacter spp.) are associated with Montastraea franksi, which reconfirms our previous findings (Rohwer et al. 2001). At a broader taxonomic scale, CFB were more often associated with Diploria strigosa than other corals. Because $D$. strigosa is a very 'mucusy' coral and this group of bacteria is particularly adept at breaking down complex polysaccharides, the composition of the mucus may be responsible for recruitment of CFB. Similarly, the $\mathrm{BC}$ association with $D$. strigosa might suggest that these bacteria are involved in fermentative breakdown of polysaccharides when the coral goes anoxic during the evening (Carlton \& Richardson 1995).

Taken together our results strongly suggest that corals harbor specific microbiotas. Nevertheless, the bacterial community we found associated with healthy Diploria strigosa differs substantially from that reported by Frias-Lopez et al. (2002). In particular, they did not find high concentrations of $\mathrm{CFB}$ and $\mathrm{BC}$ group bacteria. The reason for this difference is not clear at this time. It may be due to variations in $16 \mathrm{~S}$ rDNA sequence acquisition protocols and analyses. For example, Frias-Lopez et al. (2002) used restriction analyses to dereplicate their $16 \mathrm{~S}$ rDNA library before sequencing. This step would have biased their library toward rare ribotypes and would make the recorded percentages (e.g. Figs. 3, $4 \& 5$ in Frias-Lopez et al. 2002) non-representative of the community as a whole. Similarly, our method of picking and sequencing $16 \mathrm{~S}$ rDNAs at random would bias our results toward common ribotypes with multiple copies of the ribosomal operon per genome. Both of our methods would have isolated bacteria from the gastral cavity, which is known to contain a large number of bacteria (Herndl \& Velimirov 1985). Future studies utilizing in situ hybrid- izations and direct counts will be needed to resolve these issues.

\section{Potential roles of coral-associated bacteria}

The prokaryotic diversity within a single coral colony is clearly much higher than that of the zooxanthellae $(2$ to 3 zooxanthellae species vs at least 30 bacterial ribotypes). Unlike the zooxanthellae, however, we do not have a clear picture of the ecological roles of these bacterial associates. The taxa that occurred in multiple clones and particularly multiple samples offer the best potential for beginning to elucidate roles. A phylogenetic analysis of these bacteria (Fig. 4) suggests many possibilities. For example, many of the coral-associated bacterial ribotypes are most closely related to known nitrogen fixers and antibiotic producers. Interestingly, 9 out of the 93 ribotypes that appear more than once are most closely related to proposed endosymbionts from both terrestrial and marine organisms.

In pelagic, oligotrophic waters, microbes sequester essential nutrients within the marine microbial loop (Azam et al. 1983). By virtue of their high affinity transport systems and their large surface area to volume ratios, prokaryotes are much more efficient at scavenging nutrients at low concentrations than are eukaryotic cells (Geesey \& Morita 1979, Geesey 1982, Nissen et al. 1984, Suttle et al. 1990). Therefore, in nutrient-poor waters the prokaryotes will assimilate most of the limiting nutrients and limit primary production (Thingstad et al. 1998, Behrenfeld \& Kolber 1999, Cavender-Bares et al. 2001). Nutrient concentrations on coral reefs are low (Muscatine 1980, Rahav et al. 1989, Szmant et al. 1990, Gast et al. 1998, 1999, Gili \& Coma 1998), and therefore prokaryotes are probably assimilating most of the limiting nutrients. Indirect evidence for nutrient limitations on coral reefs comes from the observation that there is a low conversion rate of particulate and dissolved organic carbon (Ducklow 1990). Thus, corals may acquire necessary nutrients by harvesting microbes from the water column through mucus netting and indirectly via capture of Protozoa that graze on bacteria (DiSalvo 1971, Sorokin 1973, Bak et al. 1998, Ferrier-Pages et al. 1998). In addition, corals may encourage the growth of microbes by secreting fixed carbon in the form of mucus and then feed upon them. Additionally, fixed nitrogen may be obtained from coral-associated microbes that are fed, protected and provided with an anaerobic environment in the coral colony (Williams et al. 1987, Shashar et al. 1994). Finally, specialized microbiota may be important for protecting the coral animal from pathogens by occupying entry niches and/or through the production of secondary metabolites (i.e. antibiotics). These possible roles are summarized in Fig. 5. 


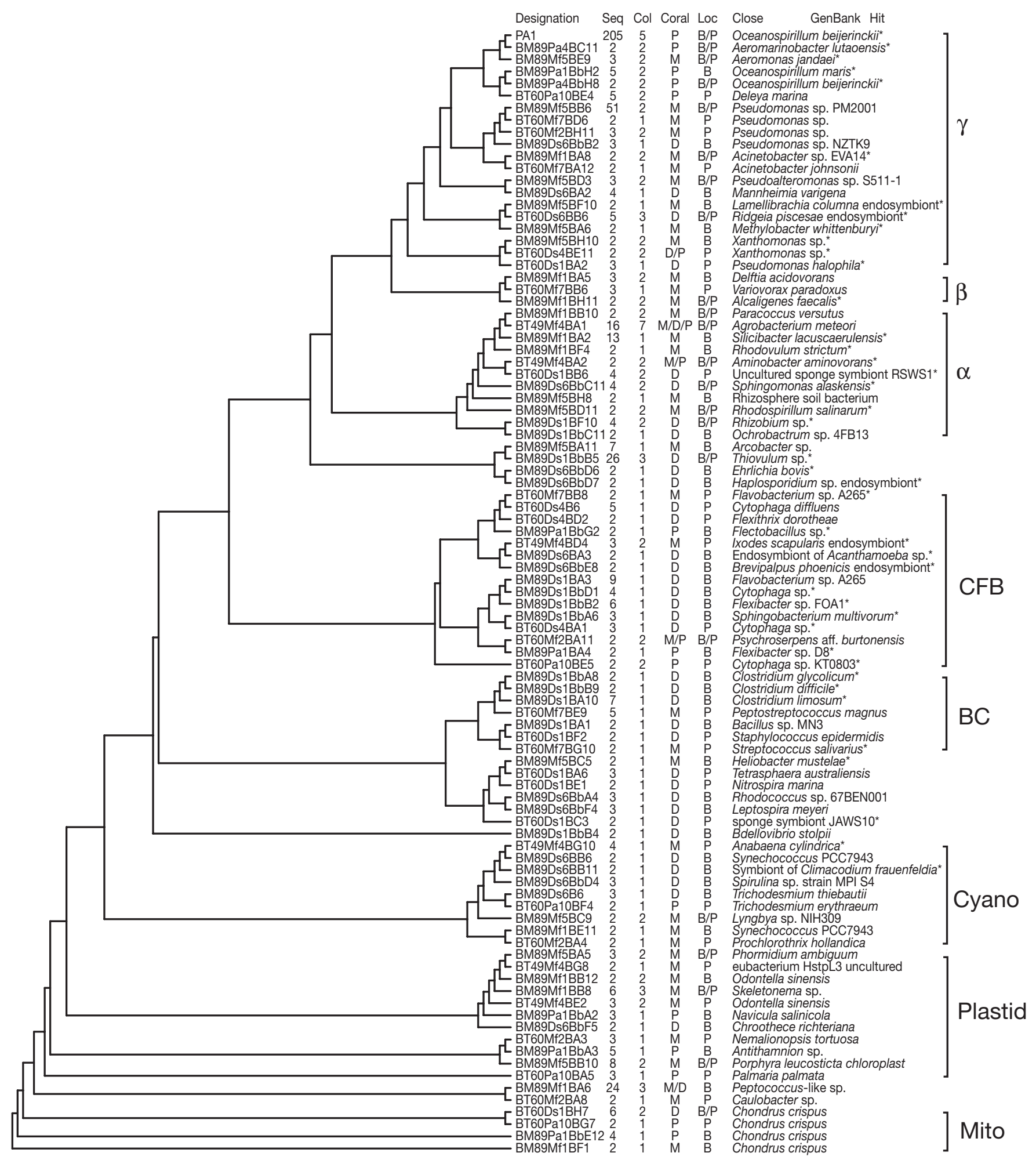

Fig. 4. Identity of bacterial ribotypes that appear more than once in the $16 \mathrm{~S}$ rDNA libraries. The Neighbor-Joining tree was drawn from a ClustalX alignment. The divisions were identified by including multiple representatives from the major microbial groups in the original ClustalX alignment. The number of clones that each sequence represented is shown (Seq), as well as the number of coral colonies $(\mathrm{Col})$, the location ( $\mathrm{Loc}_{;} \mathrm{P}=$ Panama, $\mathrm{B}=\mathrm{Bermuda}$ ) and coral species that the ribotype appeared on $(\mathrm{Coral}$; $\mathrm{M}=$ Montastraea franksi, $\mathrm{D}=$ Diploria strigosa, $\mathrm{P}=$ Porites astreoides). The closest named hit identified by a BLASTN search of GenBank is also shown. For the non-plastid/mitochondrial sequences, an asterisk indicates that the top hit was to an uncultured bacterium; in these cases the closest named bacterium was listed 


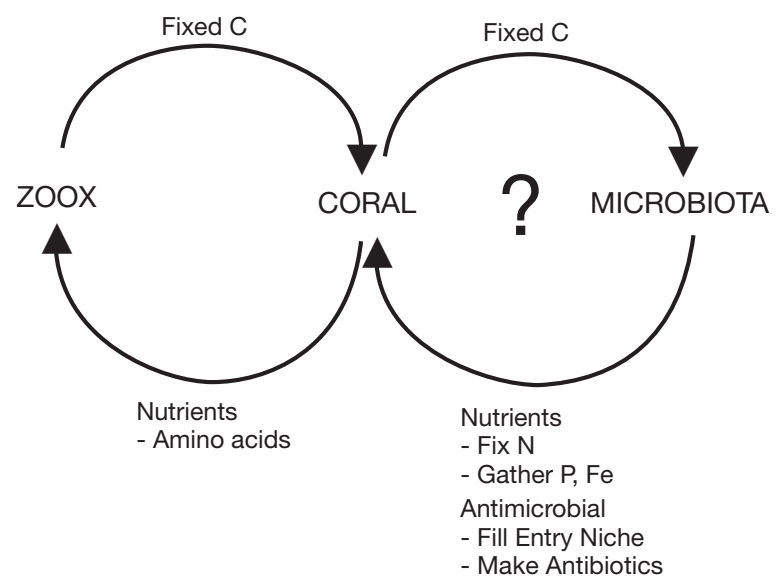

Fig. 5. Proposed model of a coral colony as a holobiont consisting of the coral animal, zooxanthellae and prokaryotes. The holobiont would also include fungi (Bentis et al. 2000), Protozoa (Toller et al. 2001), endolithic algae (Odum \& Odum 1955, Shashar et al. 1997, Bentis et al. 2000) and unknown components that have yet to be studied

\section{Coral microbiotas and disease}

Caribbean reefs have recently been decimated to an unprecedented extent by disease (Goreau et al. 1998, Richardson 1998, Harvell et al. 1999, Green \& Bruckner 2000). Microbiologists have consequently turned their attention to potential pathogens of corals (reviewed in Richardson 1998). However, the limited number studies of the normal bacterial associates of healthy corals (Santavy 1995, Ritchie \& Smith 1995, Rohwer et al. 2001, Frias-Lopez et al. 2002) undermines our ability to understand the changes associated with disease.

An important implication of the model presented in Fig. 5 is that disrupting any 1 of these components may cause physiological changes that result in coral disease or death. The threats to coral reefs worldwide give new urgency to understanding the nature of the relationships between healthy corals and their associated prokaryotes. Characterizing these organisms and documenting their patterns of distribution, as we have begun to do here, is an essential first step.

Acknowledgements. We thank Mya Breitbart and Jeremy Jackson for comments. The National Science Foundation (NSF Biological Oceanography SGER OCE 01-16900 and OCE 01-37748), the Scripps Institution of Oceanography Director's Office, the Smithsonian Tropical Research Institute, the Bermuda Biological Research Station and the San Diego State University College of Sciences provided support. Sequencing support was provided by the SDSU Microchemical Core Facility. We also thank the governments of Bermuda and the Republic of Panama (Autoridad Nacional del Ambiente, Departamento de Cuarentena Agropecuaria del Ministerio de
Desarollo Agropecuaria, Recursos Marinos) for permission to collect and export corals. This is a contribution from the Center for Marine Biodiversity and Conservation.

\section{LITERATURE CITED}

Altschul SF, Gish W, Miller W, Myers EW, Lipman DJ (1990) Basic local alignment search tool. J Mol Biol 215:403-410 Altschul SF, Madden TL, Schäffer AA, Zhang J, Zhang Z, Miller W, Lipman DJ (1997) Gapped BLAST and PSIBLAST: a new generation of protein database search programs. Nucleic Acids Res 25:3389-3402

Amann RI, Ludwig W, Schleifer KH (1995) Phylogenetic identification and in situ detection of individual microbial cells without cultivation. Microbiol Rev 59:143-169

Azam F, Fenchel T, Field JG, Gray JS, Meyer-Reil LA, Thingstad F (1983) The ecological role of water-column microbes in the sea. Mar Ecol Prog Ser 10:257-263

Bak RPM, Joenje M, de Jong I, Lambrechts DYM, Nieuwland G (1998) Bacterial suspension feeding by coral reef benthic organisms. Mar Ecol Prog Ser 175:285-288

Behrenfeld MJ, Kolber ZS (1999) Widespread iron limitation of phytoplankton in the South Pacific Ocean. Science 283: 840-843

Bellwood DR, Hughes TP (2001) Regional-scale assembly rules and biodiversity of coral reefs. Science 292:1532-1534

Benson DA, Karsch-Mizrachi I, Lipman DJ, Ostell J, Rapp BA, Wheeler DL (2000) GenBank. Nucleic Acids Res 28:15-18

Bentis CJ, Kaufman L, Golubic S (2000) Endolithic fungi in reefbuilding corals (Order: Scleractinia) are common, cosmopolitan, and potentially pathogenic. Biol Bull 198:254-260

Carlton RG, Richardson LL (1995) Oxygen and sulfide dynamics in a horizontally migrating cyanobacterial mat: black band disease of corals. FEMS Microbiol Ecol 18: 155-162

Cavender-Bares KK, Karl DM, Chisholm SW (2001) Nutrient gradients in the western North Atlantic Ocean: relationship to microbial community structure and comparison to patterns in the Pacific Ocean. Deep-Sea Res Part A 48: 2373-2395

Chao A (1984) Non-parametric estimation of the number of classes in a population. Scand J Stat 11:783-791

Colwell RK, Coddington JA (1994) Estimating terrestrial biodiversity through extrapolation. Phil Trans R Soc Lond Ser B 345:101-119

DiSalvo LH (1971) Regenerative functions and microbial ecology of coral reefs: labeled bacteria in a coral reef microcosm. J Exp Mar Biol Ecol 7:123-136

DiSalvo L, Gundersen K (1971) Regenerative functions and microbial ecology of coral reefs. I. Assays for microbial population. Can J Microbiol 17:1081-1089

Ducklow HW (1990) The biomass, production, and fate of bacteria in coral reefs. In: Dubinski Z (ed) Coral reefs. Elsevier Scientific Publishers, Amsterdam, p 265-289

Ducklow HW, Mitchell R (1979) Bacterial populations and adaptations in the mucus layers on living corals. Limnol Oceanogr 24:715-725

Ferrier-Pages C, Allemand D, Gattuso JP, Jaubert J, Rassoulzadegan F (1998) Microheterotrophy in the zooxanthellate coral Stylophora pistillata: effects of light and ciliate density. Limnol Oceanogr 43:1639-1648

Frias-Lopez J, Zerkle AL, Bonheyo GT, Fouke BW (2002) Partitioning of bacterial communities between seawater and healthy, black band diseased, and dead coral surfaces. Appl Environ Microbiol 68:2214-2228

Gast GJ, Wiegman S, Wieringa E, Duyl FC, Bak RPM (1998) 
Bacteria in coral reef water types: removal of cells, stimulation of growth and mineralization. Mar Ecol Prog Ser 167:37-45

Gast GJ, Jonkers PJ, Van Duyl FC, Bak RPM (1999) Bacteria, flagellates and nutrients in island fringing coral reef waters: influence of the ocean, the reef and eutrophication. Bull Mar Sci 65:523-538

Geesey GG (1982) Microbial exopolymers: ecological and economic considerations. ASM News 48:9-14

Geesey GG, Morita RY (1979) Capture of arginine at low concentrations by a marine psychrophilic bacterium. Appl Environ Microbiol 38:1092-1097

Gili JM, Coma R (1998) Benthic suspension feeders: their paramount role in littoral marine food webs. TREE 13: 316-321

Giovannoni S, Rappe M (2000) Evolution, diversity, and molecular ecology of marine prokaryotes. In: Kirchman DL (ed) Microbial ecology of the oceans. Wiley-Liss, New York, p 47-84

Goreau TJ, Cervino J, Goreau M, Hayes R and 14 others (1998) Rapid spread of diseases in Caribbean coral reefs. Rev Biol Trop 46:157-171

Green EP, Bruckner AW (2000) The significance of coral disease epizootiology for coral reef conservation. Biol Conserv 96:347-361

Hagström ^̊, Pinhassi J, Zweifel UL (2000) Biogeographical diversity among marine bacterioplankton. Aquat Microbial Ecol 21:231-244

Hagström Å, Pommier T, Rohwer F, Simu K, Svensson D, Zweifel UL (2002) Bio-informatics reveal surprisingly low species richness in marine bacterioplankton. Appl Environ Microbiol 67:3628-3633

Harvell CD, Kim K, Burkholder JM, Colwell RR and 9 others (1999) Emerging marine diseases-Climate links and anthropogenic factors. Science 285:1505-1510

Herndl GJ, Velimirov B (1985) Bacteria in the coelenteron of Anthozoa: control of bacterial density by the coelenteric fluid. J Exp Mar Biol Ecol 93:115-130

Herndl GJ, Velimirov B (1986) Microheterotrophic utilization of mucus released by the Mediterranean coral Cladocora cespitosa. Mar Biol 90:363-369

Hughes JB, Hellmann JJ, Richetts TH, Bohannan BJM (2001) Counting the uncountable: statistical approaches to estimating microbial diversity. Appl Environ Microbiol 67: 4399-4406

Kushmaro A, Loya Y, Fine M, Rosenberg E (1996) Bacterial infection and coral bleaching. Nature 380:396

Liu WT, Marsh TL, Cheng H, Forney LJ (1997) Characterization of microbial diversity by determining terminal restriction fragment length polymorphisms of genes encoding 16S rRNA. Appl Environ Microbiol 63:4516-4522

Mitchell R, Chet I (1975) Bacterial attack of corals in polluted seawater. Microb Ecol 2:227-233

Moesender MM, Arrieta JM, Muyzer G, Winter C, Herndl GJ (1999) Optimization of terminal-restriction fragment length polymorphism analysis for complex marine bacterioplankton communities and comparison with denaturing gradient gel electrophoresis. Appl Environ Microbiol 65: $3518-3525$

Moore LR, Rocap G, Chisholm SW (1998) Physiology and molecular phylogeny of coexisting Prochlorococcus ecotypes. Nature 393:464-467

Muscatine L (1980) Uptake, retention, and release of dissolved inorganic nutrients by marine algae invertebrate associations. In: Cook CB, Pappas PW, Rudolph ED (eds) Cellular interactions in symbiosis and parasitism. Ohio State University Press, Columbus, p 229-244
Nissen H, Nissen P, Azam F (1984) Multiphasic uptake of D-glucose by an oligotrophic marine bacterium. Mar Ecol Prog Ser 16:155-160

Odum HT, Odum EP (1955) Trophic structure and productivity of a windward coral reef community on Eniwetok Atoll. Ecol Monographs 25:291-320

Pascal H, Vacelet E (1981) Bacterial utilization of mucus on the coral reef of Aquaba (Red Sea). Proc 4th Int Coral Reef Symp 1:669-677

Paul JH, DeFlaun MF, Jeffery WH (1986) Elevated levels of microbial activity in the coral surface monolayer. Mar Ecol Prog Ser 33:29-40

Perna N, Plunkett G, Burland V, Mau B and 24 others (2001) Genome sequence of enterohaemorrhagic Escherichia coli O157: H7. Nature 409:529

Rahav O, Dubinsky Z, Achituv Y, Falkowski PG (1989) Ammonium assimilation in the zooxanthelle coral, Stylophroa pistillata. Proc R Soc Lond Ser B 236:325-337

Rath J, Wu KY, Herndl GJ, DeLong EF (1998) High phylogenetic diversity in a marine-snow-associated bacterial assemblage. Aquat Microb Ecol 14:261-269

Reaka-Kudla ML (1997) Understanding and protecting our biological resources. In: Reaka-Kudla ML, Wilson DE, Wilson EO (eds) Biodiversity II. Joseph Henry Press, Washington, DC, p 83-108

Richardson LL (1998) Coral diseases: what is really known? TREE 13:438-443

Ritchie KB, Smith GW (1995) Preferential carbon utilization by surface bacterial communities from water mass, normal, and white-band diseased Acropora cervicornis. Mol Mar Biol Biotechnol 4:345-354

Ritchie KB, Smith GW (1997) Physiological comparison of bacterial communities from various species of scleractinian corals. Proc 8th Intl Coral Reef Symp 1:521-526

Roberts CM, McClean CJ, Veron JEN, Hawkins JP and 8 others (2002) Marine biodiversity hotspots and conservation priorities from tropical reefs. Science 295:1280-1284

Rohwer F, Breitbart M, Jara J, Azam F, Knowlton N (2001) Diversity of bacteria associated with the Caribbean coral Montastraea franksi. Coral Reefs 20:85-95

Santavy DL (1995) The diversity of microorganisms associated with marine invertebrates and their roles in the maintenance of ecosystems. In: Allsopp D, Colwell RR, Hawksworth DL (eds) Microbial diversity and ecosystem function. CAB International, Wallingford, p 211-229

Santavy DL, Peters EC (1997) Microbial pests: coral disease in the Western Atlantic. Proc 8th Int Coral Reef Symp 1: $607-612$

Santavy DL, Peters EC, Kozlowski J, Wilkinson S (1995) Characterization of the bacterium suspected in the incidence of white band disease. Abstr Gen Meet Am Soc Microbiol, p 332

Segel LA, Ducklow HW (1982) A theoretical investigation into the influence of sublethal stresses on coral-bacterial ecosystem dynamics. Bull Mar Sci 32:919-935

Seguritan V, Rohwer F (2001) FastGroup: a program to dereplicate libraries of $16 \mathrm{~S}$ rDNA sequences. BMC Microbiol Bioinformatics 2

Shashar N, Cohen Y, Loya Y, Sar N (1994) Nitrogen fixation (acetylene reduction) in stony corals: evidence for coralbacteria interactions. Mar Ecol Prog Ser 111:259-264

Shashar N, Banaszak AT, Lesser MP, Amrami D (1997) Coral endolithic algae: life in a protected environment. Pac Sci 51:167-173

Small AM, Adey WH, Spoon D (1998) Are current estimates of coral reef biodiversity too low? The view through the window of a microcosm. Atoll Res Bull 458:1-20 
Sorokin YI (1973) Trophical role of bacteria in the ecosystem of the coral reef. Nature 242:415-417

Stackebrandt E, Goebel BM (1994) Taxonomic note: a place for DNA-DNA reassociation and 16S rRNA sequence analysis in the present species definition in bacteriology. Int J Syst Bacteriol 44:846-849

Suttle CA, Fuhrman JA, Capone DG (1990) Rapid ammonium cycling and concentration-dependent partitioning of ammonium and phosphate: implications for carbon transfer in planktonic communities. Limnol Oceanogr 35:424-433

Szmant AM, Ferrer LM, FitzGerald LM (1990) Nitrogen excretion and O:N ratios in reef corals: evidence for the conservation of nitrogen. Mar Biol 104:119-127

Thingstad FT, Zweifel UL, Rassoulzadegan F (1998) P limitation of heterotrophic bacteria and phytoplankton in the northwest Mediterranean. Limnol Oceanogr 43:88-94

Thompson JD, Higgins DG, Gibson TJ (1994) CLUSTAL W: improving the sensitivity of progressive multiple sequence alignment through sequence weighting, positions-specific

Editorial responsibility: Otto Kinne (Editor),

Oldendorf/Luhe, Germany gap penalties and weight matrix choice. Nucleic Acids Res 22:4673-4680

Thompson JD, Gibson TJ, Plewniak F, Jeanmougin F, Higgins DG (1997) The Clustal X windows interface: flexible strategies for multiple sequence alignment aided by quality analysis tools. Nucleic Acids Res 24:4876-4882

Toller WW, Rowan R, Knowlton N (2001) Zooxanthellae of the Montastraea annularis species complex: patterns of distribution of four taxa of Symbiodinium on different reefs and across depths. Biol Bull 201:348-359

Ward DM (1998) A natural species concept for prokaryotes. Curr Opin Microbiol 1:271-277

Wayne LG, Brenner DJ, Colwell RR, Grimont PAD and 8 others (1987) Report of the ad hoc committee on reconciliation of approaches to bacterial systematics. Int J Syst Bacteriol 37:463-464

Williams WM, Viner AB, Broughton WJ (1987) Nitrogen fixation (acetylene reduction) associated with the living coral Acropora variabilis. Mar Biol 94:531-535

Submitted: June 12, 2002; Accepted: August 21, 2002

Proofs received from author(s): October 31, 2002 